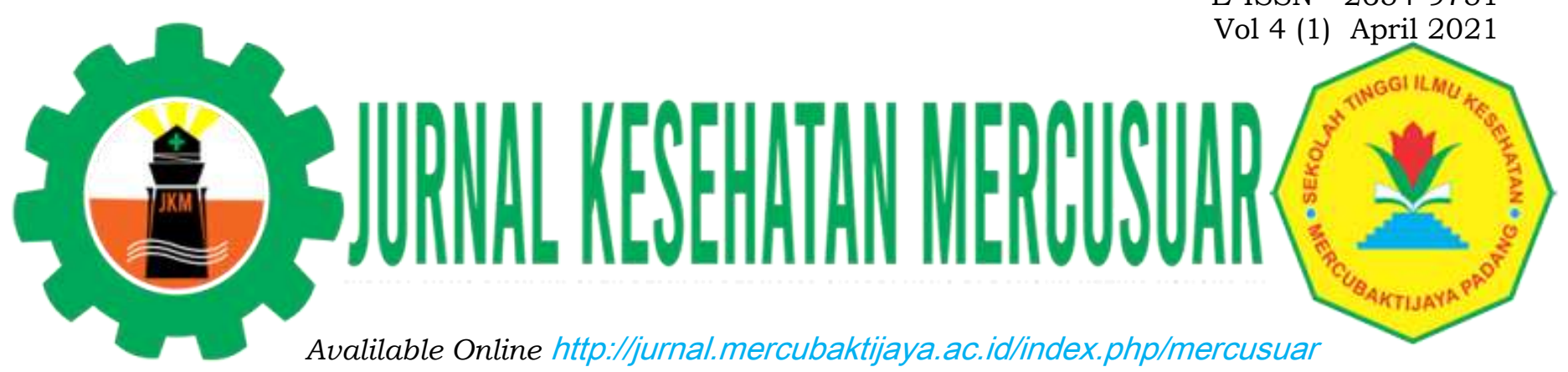

\title{
STUDI KASUS: IBU NIFAS DENGAN INFEKSI LUKA PERINEUM
}

\author{
Agustin Dwi Syalfina $^{1 *}$, Dian Irawati ${ }^{2}$, Sari Priyanti ${ }^{3}$, Ainul Churotin ${ }^{4}$ \\ ${ }^{1 * 2}$ Prodi S1 Kebidanan, Sekolah Tinggi Ilmu Kesehatan Majapahit \\ ${ }^{3}$ Prodi profesi kebidanan, Sekolah Tinggi Ilmu Kesehatan Majapahit \\ ${ }^{4}$ Prodi D3 Kebidanan, Sekolah Tinggi Ilmu Kesehatan Majapahit \\ *Email korespondensi: agustinpipin2@gmail.com
}

\begin{abstract}
Infection during the puerperium is one of the causes of the high maternal mortality rate. The incidence of infection during the puerperium is caused by suture wounds in the infected perineum. Perineal injury due to tear or episiotomy. If the wound is not properly treated, namely by keeping the genital area clean and dry, bacteria can multiply in the wound area. This study aims to describe the midwifery care of postpartum mothers with perineal infection. This research was conducted with a case study approach to the research subject Mrs. "K" aged 23 years in Randugenengan Village, Dlanggu District, Mojokerto Regency. Data collection was carried out by looking at the cohort, conducting home visits, and conducting an examination of 4 visits then the data were analyzed with related research. The results of the second visit to Mrs. " $K$ " showed signs of infection in the perineal wound, including complaints of pain and discomfort in the genitalia area, open suture wounds, there was pus, the perineal skin looked red and smelly. Management carried out daily wound care. Perform vulva hygiene, teach to a diet high in protein. Midwives need to make regular postpartum visits to detect signs of complications early so that the mother and baby remain in good health.
\end{abstract}

Keywords: Midwifery Care; Postpartum; Perineal Infection

\begin{abstract}
ABSTRAK
Infeksi pada masa nifas adalah salah satu penyebab tingginya angka kematian ibu. Kejadian infeksi pada masa nifas yang terbanyak disebabkan luka jahitan pada perineum yang terinfeksi. Luka perineum karena robekan atau episiotomi. Luka tersebut apabila tidak dilakukan perawatan secara baik yaitu dengan cara menjaga tetap bersih dan kering daerah genitalia maka bakteri dapat berkembang biak di daerah luka tersebut. Penelitian ini bertujuan untuk menggambarkan asuhan kebidanan pada ibu nifas dengan infeksi perineum. Penelitian ini dilakukan dengan pendekatan studi kasus pada subyek penelitian Ny "K" Usia 23 tahun di Desa Randugenengan kecamatan Dlanggu Kabupaten Mojokerto. Pengumpulan data dilakukan dengan melihat kohort, melakukan kunjungan rumah dan melakukan pemeriksaan sebanyak 4 kali kunjungan kemudian data dianalisis dengan penelitian terkait. Hasil kunjugan ke 2 pada $\mathrm{Ny}$ "K"menunjukkan tanda infeksi pada luka perineum antara lain adanya keluhan nyeri dan tidak nyaman pada daerah genitalia, tampak luka jahitan terbuka, ada nanah, kulit perineum tampak merah dan berbau.
\end{abstract}


Agustin Dwi Syalfina ${ }^{1 *}$, Dian Irawati², Sari Priyanti³, Ainul Churotin ${ }^{4} \mid$ Studi Kasus: Ibu Nifas dengan Infeksi Luka Perineum

Penatalaksanaan dilakukan perawatan luka setiap hari. melakukan vulva hygiene, mengajarkan untuk diit tinggi protein. Bidan penting melakukan kunjungan nifas secara rutin untuk mendeteksi tanda komplikasi secara dini sehingga ibu dan bayi tetap dalam kondisi sehat.

Kata Kunci : Asuhan Kebidanan; Nifas; Infeksi perineum

\section{PENDAHULUAN}

Angka kematian (AKI) sampai saat ini masih menjadi masalah utama di Indonesia karena capaian yang masih jauh dari target SDGs (Suitainable Development Goals) 70 per 100.000 kelahiran hidup (KH). Angka ini masih jauh dari capaian AKI tahun 2015 Indonesia 305/100.000 KH. Sebagian besar penyebab tingginya kematian ibu adalah perdarahan post partum, preeklamsia, infeksi masa nifas dan penyakit penyerta selama kehamilan. Prevalensi kasus kematian ibu dengan infeksi post partum di Indonesia pada tahun 2016 sebesar 23,5\% dari 1.015 kasus infeksi post partum dan $17,9 \%$ kasus meninggal duni dengan infeksi post partum pada tahun 2017 (Rahayu, Bakti, Andi Multazam, 2018). Faktor penyebab Infeksi masa nifas antara lain rendahnya imunitas, perawatan ibu post partum yang kurang baik, perilaku tarak makan, rendahnya status gizi ibu, personal hygiene yang tidak bersih, anemia dan kelelahan.

Infeksi post partum adalah komplikasi pada masa nifas disebabkan adanya luka pada jalan lahir seperti perineum, servik dan juga luka bekas implantasi plasenta. Perlukaan pada perineum dan servik bisa terjadi dikarenakan ibu bersalin sebelum pembukaan lengkap sudah dipimpin mengejan, bayi besar dan episiotomi. Tindakan episiotomi bermanfaat untuk menghindari tingginya derajat robekan pada perineum, mengurangi peregangan otot yang menyangga kandung kemih, mengurangi peregangan yang kuat dan lama pada otot penyangga kandung kemih (Sriani Timbawa , Rina Kundre, 2015).
Perawatan luka pada perineum (vulva hygiene) penting dilakukan untuk mempertahankan kebersihan perineum, mencegah keputihan yang berbau tidak dan gatal, mempertahankan normalitas Ph vagina, mencegah terjadinya infeksi post partum. Vulva hygiene merupakan usaha membersihkan alat kelamin bagian luar dengan menggunakan sabun dan air mengalir. Cara membersihkan jalan lahir dengan melakukan cebok setelah buang air kecil dan buang air besar dari arah depan ke belakang. Apabila terjadi infeksi pada jalan lahir, maka infeksi tersebut bisa mengakibatkan infeksi di daerah lain seperti pada saluran kencing (cystitis), servik (cerviksitis), endometrium (endometritis). Selain itu infeksi ini juga mampu mencegah kesembuhan pada luka perineum karena jaringan yang akan tumbuh menjadi jaringan baru pada luka tersebut mengalami kerusakan/nekrosis. Oleh karena itu maka peneliti melakukan penelitian yang bertujuan untuk menggambarkan asuhan kebidanan pada ibu nifas dengan infeksi perineum.

\section{METODE PENELITIAN}

Penelitian ini menggunakan metode penelitian deskriptif dengan pendekatan studi kasus. Studi kasus dilakukan dengan cara menggali data tentang asuhan kebidanan ibu nifas dengan infeksi pada luka perineum. Subyek penelitiannya adalah Ny "K" usia 23 tahun di Desa Randugenengan wilayah kerja UPT Puskesmas Dlanggu Kabupaten Mojokerto pada bulan 5 Maret 2019 - 2 April 2019. Teknik pengumpulan data menggunakan data sekunder dengan melihat 
Agustin Dwi Syalfina ${ }^{1 *}$, Dian Irawati², Sari Priyanti³, Ainul Churotin ${ }^{4} \mid$ Studi Kasus: Ibu Nifas dengan Infeksi Luka Perineum

kohort ibu untuk mengetahui data lengkap ibu hamil yang akan melahirkan untuk dilakukan pemantauan masa nifasnya serta menggunakan data primer yaitu melakukan wawancara untuk menggali informasi tentang data subyektif, data obyektif, mengimplementasikan rencana asuhan kebidanan pada ibu nifas yang didokumentasikan dengan metode SOAP. Pengambilan data primer dengan melakukan kunjungan rumah sebanyak 4 kali. Data yang sudah di peroleh kemudian di analisis secara kualitatif, dilakukan pembahasan dan pembandingan dengan penelitian yang terkait , tahap terakhir diinduksi untuk penarikan kesimpulan.

\section{HASIL DAN PEMBAHASAN}

Kunjungan nifas pertama pada 24 jam post partum pada $\mathrm{Ny}$ " $\mathrm{K}$ " didapatkan hasil bahwa NY "K" mengatakan perutnya masih terasa mules dan telah melahirkan bayinya tanggal 4 Maret 2019 secara normal di klinik bidan jenis kelamin perempuan dan berat badan (BB) 3,1 kg. Ibu mengatakan makan 3 kali sehari (menu nasi, sayur, tempe), minum kurang lebih 8 gelas sehari, perawatan diri (mandi, keramas, gosok gigi) 2 kali sehari. Hasil pemeriksaan menunjukkan keadaan umum (KU) baik, kesadaran composmentis, TD 120/70 mmHg, Nadi 80x/menit, RR 20x/menit, Suhu $=36,7^{\circ} \mathrm{C}, \quad$ tampak luka jahitan pada perineum derajat 2 yang masih basah dan dari vagina keluar lochea rubra, TFU 2 jari dibawah pusat, kontraksi uterus baik, ASI keluar lancar, mobilisasi baik. Pada pemeriksaan genetalia tampak sedikit kurang bersih karena info pasien kalau cebok tidak berani memegang alat kelaminnya karena takut ada lukanya. Penatalaksanaan yang diberikan dengan mengajurkan ibu untuk mengkonsumsi menu seimbang dengan menambah menu makan yang tinggi protein seperti ikan laut, telur, daging untuk mempercepat kesembukan jahitan pada perineum, mengajarkan cara menjaga hygiene daerah genetalia dan perawatan payudara, mengajurkan untuk sering mengganti pembalut, menganjurkan untuk memberikan ASI eksklusif dan menginformasikan tentang deteksi tanda bahaya masa nifas.

Kunjungan ke dua dilakukan pada hari ke 6 masa nifas. Ibu mengatakan keluar darah merah dari kemaluannya padahal sebelumnya berwarna coklat, alat kelaminnya terasa tidak nyaman, dan nyeri, terasa seperti bengkak pada vagina, kaki bengkak. Hasil data subyektif diperoleh makan $3 \mathrm{kali} / \mathrm{hari}$ (menu sayur, nasi, tempe, tahu), minum air putih, istirahat cukup, BAB dan BAK lancar dan aktifitas sudah bisa melakukan pekerjaan rumah tangga seperti menyapu, bersih-bersih kamar. Pemeriksaan data obyektif yaitu KU baik, TD 120/70 mmHG, nadi 84 kali/menit, RR 20 kali/menit, Suhu $36,6^{\circ} \mathrm{C}$, pada genetalia tampak jahitan perineum terlepas dan luka perineum terbuka, luka jahitan berwarna merah bengkak dan mengelurakan secret dan darah, tampak di pembalut lochea rubra, anus kelihatan kotor, ASI keluar banyak, TFU pertengahan pusat dan sympisis, kontraksi uterus baik, ada oedem pada ekstrimitas bawah. Asuhan kebidanan yang diberikan antara lain memberitahukan bahwa luka jahitan mengalami infeksi, menganjurkan ibu untuk tidak pantang makanan dengan menambah menu tinggi protein, menganjurkan ibu untuk menjaga kebersihan anogenital terutama setelah $\mathrm{BAB}$ dan BAK disertai sering mengganti pembalut, menganjurkan ibu untuk meninggikan posisi kaki ketika tidur dan tidak duduk dnegan kaki tergantung, 
Agustin Dwi Syalfina ${ }^{1 *}$, Dian Irawati², Sari Priyanti³, Ainul Churotin ${ }^{4} \mid$ Studi Kasus: Ibu Nifas dengan Infeksi Luka Perineum

melakukan perawatan luka pereineum dan vulva hygiene secara rutin setiap hari, melakukan kolaborasi dengan bidan desa untuk pemberian terapi.

Kunjungan ke III hari ke 14 post partum, Ny " $K$ " mengatakan masih terasa tidak nyaman pada jahitannya dan menu makanannya sudah terdiri dari nasi, sayur, ayam, daging, telur. Hasil pemeriksaan tentang data obyektif yaitu tanda-tanda vital (TTV) dalam batas nomal, tampak luka perineum sudah mulai menutup, tidak berbau, tidak kemerahan, tidak bengkak namum masih mengeluarkan seckret berwarna kuning, lochea sanguilenta, area anus masih kotor, TFU tidak teraba, kaki tidak oedema. Tindakan yang dilakukan peneliti yaitu menjelaskan kepada Ny "K" bahwa keadaannya sudah lebih baik dari sebelumnya, mengajarkan ibu tentang cara menjaga kebersihan daerah anus dan genetalia dan memotivasi pasien supaya tidak takut untuk memegang daerah tersebut ketika cebok, menganjurkan ibu untuk tidak tarak makan dan diit tinggi protein, melakukan perawatan luka perineum dan membersihkan daerah genetalia satu kali setiap hari.

Kunjungan ke IV (hari ke 29 post partum), Ny " $K$ " mengeluhkan keputihan sejak 4 hari yang lalu, mengeluarkan darah sedikit dan susah BAB. Pasien mengatakan makan 3 kali sehari dengan menu sayur, ayam, nasi, daging telur dan minum cukup air putih. Peneliti melakukan pemeriksaan umum dan fisik dengan hasil KU baik, luka jahitan sudah tertutup, tidak mengeluarkan nanah, tidak berwarna kemerahan, lochea alba, daerah anus bersih. Asuhan kebidanan yang diberikan antara lain memberitahukan kepad ibu bahwa kondisi luka jahitan sudah baik, menganjurkan tetap menjaga kebersihan daerah anus dan alat kelamin, menganjurkan ibu untuk mengkonsumsi makanan tinggi serat dan tinggi protein, meenganjurkan ibu untuk segera merencanakan program pemakaian kontrasepsi karen sudah menunjukkan tanda Kembali mendapatkan menstruasi, mengajarkan tentang senam nifas.

Nifas adalah masa sejak setelah bayi dan plasenta lahir sampai dengan 6 minggu setelahnya yang diikuti pemulihan kembali organ reproduksi ke posisi normal. Periode nifas penting diperhatikan dan membutuhkan asuhan kebidanan yang berkualitas karena masa yang paling banyak terjadi kematian ibu. Penyebab kematian ibu pada masa nifas adalah infeksi port partum. Infeksi pasca melahirkan yang biasa terjadi yaitu infeksi pada jalan lahir karena robekan maupun episiotomy. Luka pada jalan lahir jika tidak dilakukan perawatan secara baik dan benar menyebabkan infeksi.

Menurut Tulas et al (2017) bahwa ibu nifas yang menerapkan perawatan luka pada perineum sehingga lukanya bersih dan kering sebagian besar memiliki perilaku kebersihan diri baik. Kebersihan diri pada ibu nifas akan mencegah bakteri masuk ke sumber luka dan memberikan kenyamanan. Perawatan pada daerah genetalia dengan luka jahitan pada perineum dengan menjaga daerah tersebut tetap bersih dan kering, membersihkan daerah tersebut dari arah depan ke belakang. Cara membersihkan yang salah menyebabkan lochea mengenai luka perineum, meningkatkan kelembaban yang menunjang pertumbuhan bakteri penyebab terjadinya infeksi.

Tahapan fase penyembuhan luka perineum yaitu: tahap pertama adalah fase inflamasi yang terjadi pada 1-2 hari, tahap kedua yaitu proliferasi dalam waktu 2-5 hari, 
Agustin Dwi Syalfina ${ }^{1 *}$, Dian Irawati², Sari Priyanti³, Ainul Churotin ${ }^{4} \mid$ Studi Kasus: Ibu Nifas dengan Infeksi Luka Perineum

dan tahap ketiga disebut Fase maturasi pada 5 hari sampai dengan berbulan-bulan. Hasil penelitian Primadona dan Susilowati (2015) bahwa tanda luka perineum yang ditunjukkan oleh ibu nifas pada fase proliferasi antara lain tampak tepi luka pada kedua sisi merapat, sudah tidak keluar darah, muncul jaringan parut, permukaan luka halus, warna kulit luar putih bersemu merah dan semi transparan, da ada sebagian kecil warna kulit bekas luka tampak merah terang. Tanda hasil penelitian ini berbeda dengan tanda pada luka perineum Ny " $\mathrm{K}$ " yang menunjukkan tanda patologis diantaranya keluar darah, berwarna merah, bengkak dan keluar pus.

Infeksi pada luka perineum pada $\mathrm{Ny}$ "K" disebabkan vulva hygiene yang kurang baik dan pola makan kurang tinggi protein. Hasil penelitian Sulistianingsih dan Wijayanti (2019) bahwa faktor risiko kejadian infeksi pada luka perineum yaitu Pendidikan ibu dalam kategori dasar, perilaku pantangan makanan, jenis jahitan satu-satu, pengetahuan ibu tentang perawatan perineum yang kurang baik, perawatan perineum kurang baik, tidak patuh dalam minum obat dan robekan spontan (bukan episiotomi).

Faktor paling utama yaitu pantang makanan dimana ibu nifas yang pantang makanan 15, 434 kali lebih berisiko mengalami kejadian infeksi perineum dibanding yang tidak pantang makanan. Penelitian Rahmawati dan Triatmaja (2015) juga menunjukkan bahwa pemenuhan kebutuhan gizi pada masa nifas berhubungan dengan tingkat lama kesembuhan luka perineum. Ibu yang pemenuhan makanan dalam gizi baik maka semakin cepat ti tingkat kesembuhan luka perineumnya. Pantang makan dilakukan karena masih ada kepercayaan pada mitos bahwa untuk mempercepat kesembuhan lukan tidak boleh makan telur dan ikan laut harus dengan menu yang kering nasi sama tahu tempe. Mitos ini tidak sesuai dengan teori bahwa tinggi protein sangat penting untuk kesembuhan luka. Perilaku ini terus diterapkan karena adanya dukungan suami, keluarga dan orang terdekat.

Dukungan suami dan keluarga penting bagi ibu nifas dalam memilih perilaku Kesehatan untuk baginya dan bayi. Dukungan suami sebagai bentuk perhatian dan dorongan bagi ibu untuk melakukan tindakan seperti perilaku dalam menu makanan selama nifas. Dukungan dan informasi dari keluarga akan sangat diperhatikan karena keluarga di anggap sebagai orang yang berpengalaman dalam perawatan masa nifas sehingga ibu nifas akan menerapkan semua informasi yang di sampaikan oleh keluarga ditunjang dengan adanya dukungan suami. Hasil penelitian Yulianisa dan Mardiyah (2019) bahwa dukungan suami berpengaruh signifikan terhadap perilaku pencegahan infeksi pada luka perineum sedangkan penelitian Nurrahmaton dan Sartika (2018) membuktikan bahwa pengetahuan tentang perawatan perineum sebagai faktor yang berhubungan pada lama penyembuhan luka perineum.

Perawatan pada luka jahitan perineum dengan melakukan cara menjaga hygiene pada bagian genetalia eksterna dengan benar. Kebersihan alat kelamian di jaga dengan melakukan pencucian daerah tersebut dengan air bersih yang mengalir dan disabun Kemudian dikeringkan dengan handuk bersih. Kondisi kering ini harus dipertahankan oleh ibu nifas dan selalu cek keadaan luka dengan memakai cermin yang dipegang oleh tangan dihadapkan pada luka jahitan supaya dapat 
Agustin Dwi Syalfina ${ }^{1 *}$, Dian Irawati², Sari Priyanti ${ }^{3}$, Ainul Churotin ${ }^{4}$ | Studi Kasus: Ibu Nifas dengan Infeksi Luka Perineum

mengenali tanda infeksi secara dini. Hidroterapi sitz bath adalah metode non farmakologis untuk pemulihan luka perineum dengan menggunakan air dingin atau air hangat. Hidroterapi mampu merangsang sirkulasi darah area pelvis sehingga mampu mengurangi nyeri pada perineum dan mencegah oedem. Menurut Girsang et al (2019) hidroterapi sitz dapat dijadikan sebagai terapi dalam perawatan luka perenium, berdasarkan hasil penelitiannya membuktikan deskripsi ciriciri perubahan luka antara hari ke 1 sampai dengan ke 3 post partum dengan pemeriksaan tanda adanya eritema, ekimosis dan edema pada luka perineum ibu. Perubahan luka tampak berbeda antara hari ke 1 sampai ke 3 yang mengarah ke perbaikan luka pada hari ke 3 .

Bidan sebagai tenaga Kesehatan pada garis depan di desa memegang peranan penting dalam penanganan sedini mungkin pada komplikasi nifas untuk menghindari kematian ibu masa nifas. Pengenalan sedini mungkin adanya komplikasi masa nifas dengan melakukan kunjungan masa nifas sebanyak 3 kali yaitu 1 kali pada 6 jam sampai dengan 3 hari pasca salin, 1 kali pada hari ke 4 sampai dengan 28 dan 1 kali dilakukan pada hari ke 29-42. Bidan yang tidak menjalankan tugasnya sebagai pendidik ibu nifas, menfasilitasi ibu dalam mendapatkan pelayanan Kesehatan serta memotivasi ibu nifas untuk datang berkunjung periksa Kesehatan mempengaruhi rendahnya kualitas kunjungan nifas sehingga apabila ada tanda bahaya nifas tidak dapat diketahui dengan cepat (Widya Lestari, 2019).

\section{SIMPULAN}

Infeksi luka jahitan perineum pada Ny"K" terjadi disebabkan karena perawatan luka tidak dilakukan secara baik dan benar, perilaku pantang makanan tinggi protein, dan rendahnya perilaku personal hygiene daerah genetalia. Tanda infeksi perineum yang ditunjukan antara lain kulit perineum berwarna mera, keluar nanah, berbau dan luka jahitan terbuka/tidak menyatu antar sisi. Oleh karena itu bidan harus secara kontinue mengedukasi ibu nifas dan keluarga tentang nutrisi selama nifas, cara menjaga personal hygiene dan perawatan luka perineum serta rutin menjalin komunikasi dengan keluarga karena dukungan keluarga terdekat berpengaruh pada perilaku kesehatan ibu nifas.

\section{UCAPAN TERIMAKASIH}

Peneliti mengucapakan rasa terima kasih kepada UPT Puskesmas Dlanggu yang telah memberi ijin, Ketua STIKES dan LPPM yang telah memberi ijin dan dukungan untuk terlaksananya penelitian serta rekan prodi kebidanan untuk dukungan atas terselesaikannya penelitian.

\section{DAFTAR PUSTAKA}

Apri Sulistianingsih, Y. W. (2019) 'Faktor yang Berpengaruh terhadap Penyembuhan Luka Perineum pada Ibu Postpartum', Journal for Quality in Women's Health, 2(1), pp. 11-18.

Bina Melvia Girsang, Nur Afi Darti, Roymond Simamora, E. I. K. (2019) 'Gambaran Karakteristik Luka Perineum Pada Ibu Post Partum Dengan Hidroterapi Sitz Bath', Jurnal Keperawatan Respati, 6(3).

Ella Yulianisa, M. S. M. (2019) 'Sikap, Keterampilan Individu, dan Dukungan 
Agustin Dwi Syalfina ${ }^{1 *}$, Dian Irawati², Sari Priyanti³, Ainul Churotin ${ }^{4} \mid$ Studi Kasus: Ibu Nifas dengan Infeksi Luka Perineum

Suami terhadap Perilaku Pencegahan Infeksi Luka Perineum Ibu Postpartum', Jurnal Ilmiah Kebidanan Indonesia STIKIM, 9(4).

Erna Rahmawati, N. T. T. (2015) 'Hubungan Pemenuhan Gizi Ibu Nifas Dengan Pemulihan Luka Perineum', Jurnal Wiyata, 2(1).

Nurrahmaton Nurrahmaton, D. S. (2018) 'Hubungan Pengetahuan Ibu Post Partum Tentang Perawatan Luka Perineum Dengan Proses Penyembuhan Luka Di Klinik Bersalin Hj. Nirmala Sapni, Amd.keb Medan', Jurnal Bidan Komunitas, 1(1).

Prakirtia Primadona, D. S. (2015) 'Penyembuhan Luka Perineum Fase Proliferasi Pada Ibu Nifas', Jurnal PROFESI, 13(1), pp. 1-5.

Rahayu, Bakti, Andi Multazam, E. K. (2018) 'Kinerja Bidan Dalam Rangka Menurunkan Angka Kejadian Infeksi
Post Partum Di Puskesmas Kabupaten Polewali Mandar Sulawesi Barat No Title', Jurnal Ilmiah Kesehatan, 12(5), pp. 569-573.

Sriani Timbawa, Rina Kundre, Y. B. (2015) 'Hubungan Vulva Hygiene Dengan Pencegahan Infeksi Luka Perineum Pada Ibu Post Partum Di Rumah Sakit Pancaran Kasih GMIM Manado', Journal Keperawatan Unsrat, 3(2).

Verby Divini Prety Tulas, Rina Kundre, Y. B. (2017) 'Hubungan Perawatan Luka Perineum Dengan Perilaku Personal Hygiene Ibu Post Partum Di Rumah Sakit Pancaran Kasih GMIM Manado', Journal Keperawatan Unsrat, 5(1).

Widya Lestari, D. F. S. (2019) 'Peran Tenaga Kesehat An Dan Kualitas Kunjungan Nifas Pada Ibu Yang Memiliki Bayi Usia 2 - 12 Bulan', Jurnal Kesehatan Mercusuar, 2(1). 